\title{
The Transformation of Multimedia-Based Teaching and Learning History Encourage Interactive Students in Primary School
}

\author{
Angelica Nurainie Awang ${ }^{1}$, Mahzan Awang ${ }^{2}$, Abdul Razaq Ahmad ${ }^{3}$ \& Shakila Che \\ Dahalan $^{4}$ \\ ${ }^{1}$ SK Saint Edmund, MALAYSIA \\ ${ }^{234}$ Faculty of Education, MALAYSIA \\ E-mail: annzniee17@gmail.com
}

\begin{abstract}
History lessons are often associated with traditional and static methods of teaching and learning. Therefore, this concept paper attempts to highlight the ways of multimedia aspect that can be used as a research material and interesting transformation for the field of History. Teaching and learning History can use four techniques, namely tutorials, exploration, communication and applications. These four techniques can use Portal and Forum Rules, You-tube, CD-ROMs, History databases, word processing, presentations and using virtual libraries. Information and communication are intimately connected with one another. The diversity of these multimedia-based techniques is an extension of its application in all fields and everyday life, especially in the education system. Electronic learning introduced in schools is one of the most relevant transformations and creates encouraging interaction between students and teachers and among students themselves. Multimedia-based teaching and learning is one of the latest trends to enhance interactive skills among students and erode the perception of some who say that learning history is passive and boring. Multimedia directly encourages students to find out more information than what's in the textbook. More interesting pictures or images and sounds can steal students' attention and can encourage students to research, explore and increase their knowledge and understanding.
\end{abstract}

Keywords: transformation, interactive, multimedia

\section{Introduction}

The creation of a History curriculum in KSSR emphasizes cognitive, effective and psychomotor domains. The KSSR History Curriculum also integrates civic knowledge, skills, citizenship and civic values in its implementation within and outside the classroom. In this era of increasingly globalized globalization and information is always at their fingertips much competition has taken place to keep up with current trends and developments. As such, information and communication and multimedia technologies are extremely 
important for everyone, including educators and students alike. Starting from the educational system the use of multimedia can be transformed and expanded into various fields. In general, multimedia learning has a positive impact on students' skills and mastery of learning in school. In the context of education, learning is defined as a change in one's behaviour as a result of acquiring knowledge, skills or practices resulting from the educational process. Learning is also a learning process that consists of teachers, students and the subject being taught. The aim of History Education is to foster the country's loyalty and pride as Malaysians.

Starting in 2013, the Ministry of Education Malaysia has taken a smart step in the pursuit of passing on the history of science to the younger generation by requiring students to pass a history course in the Malaysian Certificate of Education (SPM) examination. For high school students it is not a big issue as they have been exposed to this subject in the past even though they were initially less responsive than other subjects. Under the new curriculum, the Primary School Curriculum (KSSR), History subjects are a mustlearn for all students from Year Four to Level II. The government proposes compulsory History subjects at all primary schools throughout the country to expose students to the history of national development from the early years. The civic elements that have been applied in the history of History are for students to appreciate the importance of History and to better understand the state of society in their own country.

Former Prime Minister YAB Datuk Seri Abdullah Ahmad Badawi said "History is an important element of civilization. The younger generation needs to gain a deeper understanding of the nation's history and national development." On August 25, 2010, Dr. Mohd Puad Zarkashi (Deputy Education Minister) at the time announced the ministry The subject decided to teach History in Primary School in 2014. But the desire to expand this fading historical knowledge requires a new paradigm shift in terms of teaching and learning as time goes on to meet the challenges and advances of the 21 st century. This is because students today are less interested in teaching techniques that involve writing notes and using blackboard only without the more interesting elements. In line with the rapid development of technology, teachers need to take the initiative to use technology to facilitate knowledge acquisition and encourage active participation of students. The use of multimedia directly will make teaching interesting, students understanding enhanced and students overall and interactive participation. It means, that the combination of multimedia elements and computer programs applied in teaching can serve as a means of communication that stimulates a variety of senses to process information.

\section{The Benefits of Multimedia Learning}

In the Malaysian education system in the 21 st century, the teaching and learning process that takes place in schools is considered to be a powerful force or catalyst for developing students with soft skills as suggested. In line with the global technological development of our country's educational system, we also emphasize the multimedia technology-based approach that begins with the establishment of the next Smart School in national schools. Technology transformations such as multimedia can transform teaching and learning techniques between teachers and students in all disciplines and need to be applied in primary schools as well. Multimedia makes it easy for teachers to present teaching materials and students feel involved in the interactive learning process.

Multimedia means a lot of media or various media including audio, video and communication tools. This device contains elements of sound, text, graphics, video, and animation used as communication tools, communicating information, knowledge, skills, appreciation, and commitment. According to the Dictionary of the House, multimedia such as computers are electronic devices that store information on a magnetic disk or tape, analyse it and produce further information as needed. When this multimedia transformation was introduced in primary school it provided a solid foundation and early preparation for students to compete globally while inculcating the spirit of history in their own country. This directly brings about a holistic change for each student to be more competitive in the process of claiming knowledge and thus benefiting the national education system.

The role of multimedia also promotes interactivity during the learning process and is appropriate for children or students in primary schools with high curiosity. (Dollah Abdillah \& Hussain Munir, 1995; Shakila Che Dahalan, 2015), is integrated during the learning process using multimedia, interactivity is an important factor. According to Warsita (2008), interactive means the purpose of two-way communication or something that is action-oriented, active and interrelated, and reciprocal. Thus, the interaction of the word interaction is very synonymous in the world of education where collaborative methods and constructivism engage students actively instead of just listening to teachers' explanations. Through interactive learning students have the opportunity to ask questions, answer questions, come up with ideas and do assignments given by the teacher individually or in groups. This way of learning focuses on the process but does not emphasize it the result that students gain knowledge through their own experience rather than memorizing techniques. 
According to Sharifah Nor Puteh (2010), there are recent studies showing that the practice of historical thinking in the classroom is still at a moderate level. This is because the teaching and learning of history in the classroom still depends on textbooks (Gillaspie \& Davis, 1997: Van Hover \& Yeager, 2004: Siti Hawa Abdullah, 2008). Bill Gates (1999), in his book Business @ The Speed of Thought, states that personal computers can transform traditional learning methods that require teachers to provide a hands-on approach that allows students to explore information in their own capacity. In conclusion, the use of multimedia among elementary students has a positive effect on fostering interaction and communication skills while making this learning technique more effective. This is because students or children can easily grasp and understand every single thing they are taught, especially historical subjects that are considered new and contain many facts.

All of the above findings provide a clear picture of the transformations taking place in technology, especially multimedia, to make teaching more successful. In addition, it is considered to be helpful to students who are low performing, uninterested and passive during the learning process. Teachers need to act as facilitators in promoting interpersonal communication or communication skills with students. In addition, teachers play a role as early childhood guides for students to apply high-level thinking skills in the history of primary school to enable new ideas to emerge. The impact of this multimedia material on history subjects is supported by the opinion expressed by Rossafri Mohamad and Wan Ahmad Jaafar Wan Yahya (2007) that students enjoy using multimedia and can stimulate learning because the process of learning history is no longer teacher-cantered. This is because students are able to access information independently and whenever needed.

\section{Issues and Challenges}

In elementary school, history is considered less important and most students say they have trouble remembering facts, are not interested, considered boring subjects, are passive and have no connection to their lives at all. These negative perceptions need to be transformed through various transformations in multimedia by actively encouraging student engagement and establishing multidimensional communication. Previous studies have not studied the use of multimedia in teaching and learning in primary schools because History subjects are not compulsory subjects and are not included as the main subject in the UPSR examination. In addition, they give reasons that they are not interested because many historical information needs to be memorized and do not have enough time to read history books. This show, students do not have a high patriotic attitude to the history of their own nation and the history of the country. Therefore, today's history teachers need to be proactive by transforming multimedia-based teaching and learning techniques that are relevant to their content while promoting effective interactive learning.

History is a subject that deals with facts about the past and forms the basis for present and future life. However, there are still students who consider history subjects to be boring subjects to study and no fun activities throughout the lesson. Teacher teaching methods are also a factor for students not being interested and bored as no 'hands-on' activity is conducted but rather as a mere explanation. This issue continues because the methods, techniques, strategies and theories of learning are not fully implemented during the teaching-learning process that should utilize a variety of interesting technologies in a structured plan. The findings of previous studies have found that this phenomenon occurs because the approaches, methods and strategies used by teachers are considered out dated and out dated. According to Che Mohd Noor \& Ahmad (2015), it is stated that during the process of teaching and learning the history subject, there are still teachers who use textbook methods or techniques solely in their teaching and cause students to lose interest in being active in the classroom. As such, chalk and talk are a common practice in the classroom. This is because the refinement should not continue because it will eliminate the student's interest in the history subject and reinforce the student's interpretation of the subject as boring.

Through insights from Development sources Education 2001-2010, one of the causes of this problem is that the majority of teachers are still using traditional teaching methods and using Information and Communication Technology (ICT) to attract and not be able to stimulate student learning in that subject, Ministry of Education Malaysia (2001). The challenges that occur in schools are that teachers often deal with students of different levels in terms of ability and achievement. In such situation, teachers should be proactive by choosing attractive multimedia methods that will actively stimulate students and enable students to understand concepts more clearly. The wisdom of teachers in technology can not only attract students but also produce a meaningful learning. Teachers create interactions with students through tutorials and share various inputs on historical facts that can be downloaded and displayed on the website. However, teachers also sometimes have other commitments and face time constraints to download and find learning materials to share with students since the time allotted for teaching history in schools is quite limited. On the contrary, teachers who are less knowledgeable should recognize that they must deepen and hone their knowledge and skills in using technology in the classroom. 
Further challenges that were often debated in the past were in terms of infrastructure and infrastructure especially in rural, rural and even suburban schools. Problems arising from this aspect of infrastructure constraints impede or undermine the implementation of multimedia technology-based teaching in the classroom. This method will require complete equipment and hardware such as a sufficient number of students per class and high-speed internet access. In addition, sometimes existing infrastructure is damaged and cannot be replaced because of budget constraints. In addition, there are inefficient systems of information technology maintenance in schools that lead to multimedia transformation cannot be fully applied. Technical assistance should be available to all schools in maximizing the use of technology in the education world.

The above statement is consistent with Bayrei (2008) and Dnyaneshwar (2011), considering that the process of integrating information technology in teaching and learning requires adequate infrastructure such as computer lab facilities, equipment related to the use of information technology as well as adequate and efficient computer preparation and maintenance.

\section{Transformation of Teaching and Learning History}

Education Development (PIPP) 2006-2010 has provided infrastructure such as computer labs complete with hardware including internet facilities in schools for teaching and learning purposes. In line with this, administrators, teachers and students are also exposed to a wide range of technologybased knowledge and skills over time. In addition, the Ministry of Education Malaysia (KPM) provided materials in the form of books, courseware, educational kits and CDROMs distributed to primary and secondary schools (Ministry of Education Malaysia 2001). However, the material is limited and not comprehensive as there are many schools that do not yet enjoy the facilities. Therefore, the ministry needs to constantly monitor and increase the allocation to prevent most teachers from returning to conventional teaching methods.

In line with the changing times and developments of the education system in the new millennium, the learning process needs to be diversified by highlighting multimedia and making interactive transformations to see how effective it is for all learners. The introduction of multimedia in the teaching and learning process is a smart move for students to tap into the history of the world and to help teachers and students access historical resources to share them to enhance their soft skills as recommended by the government. This situation can serve as a foundation for the Ministry of Education Malaysia to create more historical websites based on Malaysian syllabus and to include materials that are interesting and appropriate for primary school students. However, this does not mean that multimedia will control all learning processes and dominate the existing curriculum.

The use of multimedia is one of the alternatives to increasing the interest of learning because the purpose of multimedia software is to develop students' thoughtful student through interactive learning (Khir Jauhari Alias, 2000). The use of multimedia can help students be more active in learning history as further information will be obtained quickly and accurately. These interactions are twoway interaction (interactivity) between the student and the computer while the teacher acts as facilitator or mentor. This strategy shows that student-cantered learning needs to be applied on a regular basis that directly promotes historical thinking, enhances students' cognitive and academic abilities in solving problems or issues. As every teacher adheres to the changes that occur in education, teachers need to master their own web site, plan their learning better and communicate with students whenever they need it.

The introduction of technology such as multimedia has transformed teaching and learning techniques between teachers and students. Multimedia including media in one software has made it easier for teachers to deliver teaching materials and this allows students to feel involved in interactive learning processes. In addition, the use of interactive multimedia software that can be used in teaching and learning in the classroom can meet a variety of student learning styles either individually or as a group activity. Findings from previous studies have also provided preliminary insights and indications that interesting elements in multimedia can help improve student achievement. Given the importance of technology resources in teaching and learning today, it is appropriate that multimedia transformational studies to foster student engagement should start from the very beginning, in primary school.

The role of multimedia is not only concerned with high school students and adults but also needs to be addressed to students in primary school as a teaching tool and tailored to their level. The approach used for children in primary school should be different from that of high school students. Teachers should be aware of the techniques and methods of presenting the content to be presented which are interesting, concise and easy to understand. Likewise, the preparation of materials and activities to be carried out throughout the learning process can be carried out with clear guidance. There are two positive views that also support the use of technology in teaching-learning so that the inputs and outputs obtained and produced in the field of history are more quality: With the advancement of technology and the 
digitization of historical resources, history teachers have been able to access, download and use historical resources through historical websites for use in the teaching and learning process of history in the classroom (Huistra \& Mellink, 2016). Thus, students have the opportunity to study historical sources by interpreting and interpreting history based on historical evidence to enhance their understanding of history while also enhancing students' intellectual processes (Merkt, Werner \& Wagner, 2017).

The process of learning and passing on knowledge from teachers to multimedia-based students should cover all aspects related to specific techniques, strategies, methods, tools and resources. When methods, resources and programs are tailored to the student's learning level such as how to present the lessons and the steps involved in learning activities, the student's academic achievement and attitude change. Using multimedia teachers can redefine the areas that need to be emphasized. Instead of using this multimedia material, students are free to explore, move and use their entire senses. At the beginning the history teacher should guide students to access information from multimedia encyclopaedia or materials from the internet and then manipulate the information collected. Transformations and improvements made to the subject can foster critical thinking, problem solving, authentic learning experiences and build student knowledge through social interaction.

In terms of teacher preparation and skills it is necessary to use multimedia that meets the curriculum requirements and supports an approach to the teaching and learning process in the classroom which can be seen in the teaching and learning aspects of multimedia student teaching. It is the wisdom of teachers to apply computer technology and learning aids by making various innovations to be successful as a scientific medium to their targets. Also, when teachers are planning for a teaching process first the teacher needs to ensure that the technology is in good working order so that the activities that the students will carry out are not interrupted and that they do not meet the objectives. This means that individual or group learning shows that students enjoy using multimedia, which learning is fast, that they can see and have an active communication environment that motivates students and that they can provide instant feedback.

In addition, infrastructure constraints and infrastructures need to be addressed jointly by the school administration, PPD, JPN with the support of the Ministry of Education Malaysia to bridge the educational gap between urban and rural students. Although learning to use computers can be practiced everywhere, problems still exist because not all students have computers at home and not all schools have internet access. The imbalance in computer distribution especially in rural schools should be noted and the facilities provided should be in line with what the students in the city enjoy. 4G high speed internet access needs to be upgraded so that the internet access provided is best for every school in the country. These measures and approaches have been intensively researched by the Ministry of Education in collaboration with the Malaysian Institute of Microelectronic System (MIMOS) to achieve the objectives of Computer Policy in Education.

\section{Conclusion}

Historical teaching and learning materials programmed in the form of multimedia delivered with diagrams, data, images, text, animations, sounds, sounds, and videos make text reading more interesting and enjoyable as it delivers sound and animation. This benefits not only the students as a whole, but also benefits the teachers in particular in terms of improving skills and knowledge regarding the use of technology. Thus, it can be concluded that multimedia aids in teaching and learning are very helpful in giving students an understanding of a topic they wish to teach, especially given the historical facts. History teachers also play a role in diversifying their teaching methods and techniques to assist students and ensure that the teaching and learning process goes smoothly as planned.

The field of History is nothing new in the world of education and history is also rapidly expanding and needs to be explored widely so that all information and facts do not deviate from the real history. It is time for every History teacher of all levels to use all of their technological skills to transform and pro-actively engage students with historical thinking skills because of the rich resources, information, facts, and historical evidence that students can explore and discover. In short, interactive multimedia is a way of making students from a passive recipient of information to an active participant. In conclusion, multimedia has become a very important teaching tool and medium for history subjects especially for students in this new age where it will be a key catalyst in future nation building.

\section{References}

[1] Azwan Ahmad, Abdul Ghani Abdullah, Mohammad Zohir Ahmad, Abd. Rahman Hj Abd. Aziz. 2005. Kesan Efikasi Kendiri Guru Sejarah Terhadap Amalan Pengajaran Berbantukan Teknologi Maklmumat dan Komunikasi (ICT). Jurnal Penyelidikan Pendidikan. Jilid 7.

[2] Abd. Rahim Abd. Rashid. 1989. Strategi Pengajaran Sejarah KBSM. Selangor: Penerbit Fajar Bakti Sdn.Bhd 
[3] Ahmad Rizal Madar dan Yahya Buntat, 2011. Keupayaan Visualisasi Pelajar Melalui Perisian Animasi Grafik. Skudai: Universiti Teknologi Malaysia.

[4] Dorsett, R. 1990. Dalam: Chin Sak Fatt (1993). TInjauan Penggunaan Komputer Dalam Pengurusan Dan Pembelajara. Projek Sarjana Muda UTM.

[5] Ismail Zain. 2000. Aplikasi Miltimedia Dalam Pengajaran. Kuala Lumpur: Utusan Publications \& Distributors Sdn.Bhd.

[6] Jamalludin Harun \& Zaidatun Tasir. 2003. Multimedia dalam Pendidikan.Bentong: PTS Publications.

[7] Johansson, P. 2017. Learning study as a clinical research practice to generate knowledge about the learning of historical primary source analysis. Educational Action Research, 25(1), 167-181.

[8] Kementerian Pendidikan Malaysia. Pembangunan Pendidikan 2001-2010: Perancangan Bersepadu Penjana Kecemerlangan Pendidikan.

[9] Lee, B. N. 2013. TMK dan pengajaran-pembelajaran Sejarah di sekolah. Seminar Pendidikan Sejarah dan Geografi 2013, UMS, 29-30 Ogos 2013, 106-115.

[10] Mohd Mahzan Awang, Abdul Razaq Ahmad, Jamalul Lail Abdul Wahab, \& Nordin Mamat. 2013. Effective teaching strategies to encourage learning behaviour. IOSR Journal of Humanities and Social Science, 8(2), 3540.

[11] Ramakrishnan, Renuka, Norizan Esa dan Siti Hawa Abdullah. 2013. Kesan Penggunan Sumber Digital Sejarah terhadap Amalan Pemikiran Sejarah. Pulau Pinang: USM.

[12] Rossafri Mohamad dan Shabariah Mohamad Shariff. 2011. Kesan Penggunaan Laman Sosial ke atas Kaedah Perbincangan di dalam Pengajaran dan Pembelajaran Mata Pelajaran Sejarah. Jurnal Teknologi Pendidikan Malaysia 1(1): 75-80.

[13] Rozinah Jamaludin. 2005. Multimedia dalam Pendidikan. Kuala Lumpur:Utusan Publications and Distributors Sdn. Bhd.

[14] Rusmini Ku Ahmad. 2012. Integrasi Teknologi Maklumat dan Komunikasi dalam Pengajaran Dan Pembelajaran. http://www.iab.academia.edu/RusminiKuAhmad/Papers/ 524734/Integrasi_Teknologi_Maklumat dan_Komunikas i_Dalam_Pengajaran_dan Pembelajaran 10 April 2012

[15] Shakila Che Dahalan. 2015. Penggunaan teknologi maklumat dan komunikasi dalam kemahiran pemikiran sejarah oleh guru pelatih. Tesis Sarjana, Fakulti Pendidikan, Universiti Sains Malaysia 